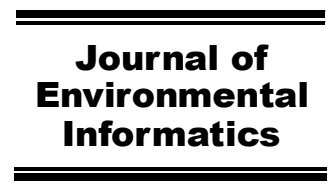

www.iseis.org/jei

\title{
Evaluating the Impact of Long Term Hydrodynamic Conditions on the Release of Metals from Contaminated Sediments in Taihu Lake, China
}

\author{
P. F. Wang, N. Geng, C. Wang*, J. Qian, J. Hou, and N. Qi \\ Key Laboratory of Integrated Regulation and Resource Department on Shallow Lakes, Ministry of Education, \\ College of Environment, Hohai University, Nanjing 210098, China
}

Received 25 September 2013; revised 11 January 2015; accepted 17 January 2015; published online 12 January 2016

\begin{abstract}
The effects of hydrodynamic conditions on sediment geochemistry, suspended solids, and the release of metal from metal-contaminated sediments were analyzed in a 23-day lab experiment involving two different experimental treatments $(14 \mathrm{~cm} / \mathrm{s}$ and $3.2 \mathrm{~cm} / \mathrm{s}$ ). At seven different points in time (after 0, 1, 3, 6, 10, 16, and 23 days) the sediment and water physical-chemical conditions and the amount of metal released into the surface water were determined. The amounts of filterable metals in the surface water increased by a factor of 21 and $4.1(\mathrm{Cd}), 10$ and $1.7(\mathrm{~Pb}), 13$ and $1.8(\mathrm{Cu}), 3.6$ and $1.7(\mathrm{Cr}), 3.7$ and $1.5(\mathrm{Ni}), 11$ and $4.7(\mathrm{Fe})$, and 7.2 and $0.12(\mathrm{Mn})$ times in the $14 \mathrm{~cm} / \mathrm{s}$ and $3.2 \mathrm{~cm} / \mathrm{s}$ treatments, respectively, after 23 days. Cr was the metal that bound most strongly to suspended solids, and $\mathrm{Cd}$ was the most readily released into the surface water. The metal equilibrium between dissolved and solid states was reached approximately 10 days after the experiment began. $\mathrm{Pb}$ required the longest time to reach equilibrium, whereas $\mathrm{Cu}$ required the least. Mn was the most easily affected by the hydrodynamic conditions. Results indicated that hydrodynamic conditions can dramatically enhance the mobility of metals, which may result in the release of sediment-bound metals to the surface water, and different metals show different characteristics during the release.
\end{abstract}

Keywords: metal release, hydrodynamic conditions, sediment, metal characteristics, suspended solids

\section{Introduction}

Heavy metals are often released from the sediment into the surface water through resuspension during sediment disturbances such as dredging, vessel movements, bioturbation, storms, and waves (Eggleton and Thomas, 2004; Kalnejais et al., 2010; Roberts, 2012; Singh et al., 2000). Taihu Lake, the third largest freshwater lake in China, is located in the southeastern part of the Yangtze River Delta. It has a catchment area of $36,500 \mathrm{~km}^{2}$, a surface area of $2,338.1 \mathrm{~km}^{2}$, and an average water depth of $2.4 \mathrm{~m}$ (Authority, 2000). Heavy metals in the sediment of shallow lakes such as Taihu are easily resuspended by hydrodynamic forces and the concentrations of metals in the surface water tend to increase immediately after hydrodynamic changes. Heavy metal contaminants in the surface water are a potential ecological risk because of their biotoxicity (Gao and Chen, 2012; Mattiuzzo et al., 2007; Roberts, 2012). The rate at which metal is released during resuspension is strongly influenced by sediment properties including grain size, sulfide content, organic matter content and the presence of hydrous metal oxides of iron and manganese (Campana et al., 2013; Cantwell et al., 2008). The mechanisms of metal release likely

${ }^{*}$ Corresponding author. Tel.: 86-025-83787332; fax: 86-025-83787332.
E-mail address: cwang@ @hu.edu.cn (C. Wang).

SSN: 1726-2135 print/1684-8799 online

(C) 2016 ISEIS All rights reserved. doi: 10.3808/jei.201500318 include ion-exchange reactions, stabilization by sediment-derived ligands and colloid formation and mobilization (Cantwell et al., 2008; Kalnejais et al., 2010). Previous studies have demonstrated that metals are released in the aqueous phase due to sulfide oxidation and other mobilizing processes and are then reabsorbed or precipitated again to different extents depending on the metal (Calmano et al., 1994). Many of the studies that have been previously conducted involved oscillating grids and stirrers that disturb the sediment. A laboratory-based erosion chamber was used to quantify the release of dissolved metals ( $\mathrm{Fe}, \mathrm{Mn}, \mathrm{Ag}, \mathrm{Cu}$, and $\mathrm{Pb}$ ) due to resuspension in Boston Harbor, Massachusetts, USA (Kalnejais et al., 2010). Zheng et al. (2012) used a pneumatic annular flume to simulate the natural wind forces affecting the sediments present in shallow lakes to evaluate the concentrations, variations and partitioning of heavy metals $(\mathrm{Cd}, \mathrm{Pb}, \mathrm{Cr}, \mathrm{Ni}, \mathrm{Cu}$, and $\mathrm{Zn})$. De Jonge et al. (2012) showed that increasing oxygen concentrations can enhance the mobility of trace metals in sediment by using two containers with a circulating water system. However, in these studies the hydrodynamic conditions were not adequately taken into consideration. Water flow in Taihu Lake follows a certain pattern with hydrodynamic conditions remaining stable in most areas (Zou et al., 1996). The manner in which metal reaches equilibrium conditions is a long-term process. Many studies have focused on the adsorption and release of metal over short time periods (Cantwell et al., 2008; Huang et al., 2012; Kalnejais et al., 2010; Zheng et al., 2012). For this reason, it is very important to use an experimental process that can simulate 
natural hydrodynamic conditions in assessments of the characteristics of metals in balance.

The main objective of the present study is to experimentally evaluate the effects of different hydrodynamic forces in the overlying surface water on sediment geochemistry and on the release of metals from metal-contaminated sediments over time.

\section{Materials and Methods}

\subsection{Sediment Sampling}

Natural sediment was sampled in June 2010 from Zhushan Bay in Taihu Lake $\left(31^{\circ} 25^{\prime} 24^{\prime \prime} \mathrm{N}, 120^{\circ} 02^{\prime} 52^{\prime \prime} \mathrm{E}\right)$. The sampling site was chosen based on its high metal concentration (Zheng et al., 2012). Subsurface sediment samples were collected using a stainless steel Peterson grab sampler (WHL 15-HL-CN) in polyethylene bags. The samples were immediately placed in polyethylene boxes and transported to the laboratory. They were stored at $4{ }^{\circ} \mathrm{C}$ until the start of the experiment.

\subsection{Experimental Setup and Design}

Two hydrodynamic flumes that were each divided into three parallel polypropylene containers $(200 \times 30 \times 40 \mathrm{~cm})$ and connected to a circulating water system (Figure 1) served as treatment groups. A fixed volume of sediment $(150 \times 30 \times$ $10 \mathrm{~cm}$ ) was added to each of the containers. $1000 \mathrm{~L}$ of tap water (Zheng et al., 2012) were stored prior to the experiment in the reservoir. A sink $(200 \times 100 \times 50 \mathrm{~cm})$ served as the control group and the sediment was kept in three parallel polypropylene containers $(85 \times 17 \times 10 \mathrm{~cm})$ in the sink. There was slight stir to homogenize the sediment in each container and then the sediment stabilized for $12 \mathrm{~h}$ before the experiment commenced. The regular flow speed in Taihu Lake is $10 \mathrm{~cm} / \mathrm{s}$ when no wind is present. In the two flumes, water was pumped at approximately 80 and $20 \mathrm{~m}^{3} / \mathrm{h}$ from the reservoir into the right container. The surface water depth was adjusted to $10 \mathrm{~cm}$. The sediment-water ratio in the control group was similar to the treatment group. After an equilibration period, the flow speed of treatment 1 was approximately $14 \pm 1.3 \mathrm{~cm} / \mathrm{s}$, and the flow speed of treatment 2 was approximately $3.2 \pm 0.8 \mathrm{~cm} / \mathrm{s}$. The flow speed was monitored and kept constant throughout the entire experimental period using an Acoustic Doppler Velocimeter (ADV).

At seven different points in time (after 0, 1, 3, 6, 10, 16, and 23 days) the redox potential (Eh), $\mathrm{pH}$ and temperature of the sediment were measured in situ to discount the effects of disturbances. Sediment samples were taken before and after the experiment to avoid disturbances and then frozen at $-80^{\circ} \mathrm{C}$ until further analysis. $\mathrm{Eh}, \mathrm{pH}$, temperature, dissolved oxygen (DO) and the electrical conductivity (EC) of the surface water were measured in situ. Surface water samples were taken from each container and stored in $500 \mathrm{~mL}$ polypropylene bottles for granulometric analysis and TSS measurement. $100 \mathrm{~mL}$ water samples were acidified to $\mathrm{pH}<2$ using concentrated nitric acid and stored in acid-washed polypropylene bottles at $4{ }^{\circ} \mathrm{C}$ for metal analysis. Tap water was added to the reservoirs after sa- mpling to maintain the original water volume. The $\mathrm{pH}$, temperature, DO, EC, turbidity, Eh levels and particle size of the overlying water were measured with the $\mathrm{HACH} \mathrm{pH}$ Sension2, the Dissolved Oxygen Sension6, the Conductivity Sension5, the Turbidimeter 2100P Portable Monitors, the FJA-4 ORP Automatic Monitor and the Mastersizer 2000, respectively.

\subsection{Analytical Method}

First, $100 \mathrm{ml}$ water samples were filtered through a 0.45 $\mu \mathrm{m}$ cellulose acetate membrane to collect the suspended solids. Then, the membranes were put into an oven and heated at $105{ }^{\circ} \mathrm{C}$ for $6 \mathrm{~h}$. The TSS contents were calculated using the difference in dry weight of membranes before and after filtering.

Levels of trace metals ( $\mathrm{Cd}, \mathrm{Cr}, \mathrm{Cu}, \mathrm{Zn}, \mathrm{Ni}$, and $\mathrm{Pb}$ ) and of $\mathrm{Fe}$ and $\mathrm{Mn}$ were measured in unfiltered surface water and in surface water filtered through a $0.45 \mu \mathrm{m}$ cellulose acetate filter. Particulate-bound metals in the surface water were calculated by subtracting the concentrations of dissolved metal from the total concentrations of each metal. Sediment and TSS samples for metal determinations were pretreated using the method described by a previous study (Zheng et al., 2012). Trace metals in surface water, TSS, and sediment were analyzed using a Perkine-Elmer, SCIEX Elan 9000 Inductively Coupled PlasmaMass Spectrometer (ICP-MS, Agilent 7700). The amount of acid volatile sulfide (AVS) in the sediment was determined as described by van Griethuysen et al. (2002). The $\mathrm{BaCl}_{2}-\mathrm{H}_{2} \mathrm{SO}_{4}$ forcing exchange method (Zhang et al., 2010) was used to determine the cation exchange capacity (CEC).

All sampling equipment was rinsed with ultrapure water and all reagents were of analytical grade, except the nitric acid (guaranteed grade). Instrumental detection limits of heavy metals for this study were $\mathrm{Cd}>0.03, \mathrm{~Pb}>0.2, \mathrm{Cu}>0.2, \mathrm{Cr}>0.30$, $\mathrm{Ni}>0.5, \mathrm{Zn}>0.5, \mathrm{Fe}>20, \mathrm{Mn}>0.5 \mu \mathrm{g} / \mathrm{L}$. Blanks, three duplicates and standard reference materials (SRMs) issued by the Standardization Administration of the People's Republic of China (SAC) were used to ensure analytical accuracy. A series of certified GSB solutions were used for water analysis, and a Stream Sediment GBW07347 was used for TSS and sediment measurements. Recoveries were within $10 \%$ of the certified values.

\subsection{Statistical analysis}

Correlation analysis and principle component analysis (PCA) were performed by means of SPSS 17.0. The data regarding heavy metal transportation were fit using Origin 8.0.

\section{Results}

\subsection{Sediment Geochemistry}

Information regarding the physical-chemical conditions of the sediment before the start of the experiment is presented in Table 1.

Significant differences were observed between initial values and those recorded at 23 days in Eh, total organic carbon (TOC) and AVS in the surface sediment of these treatments. 


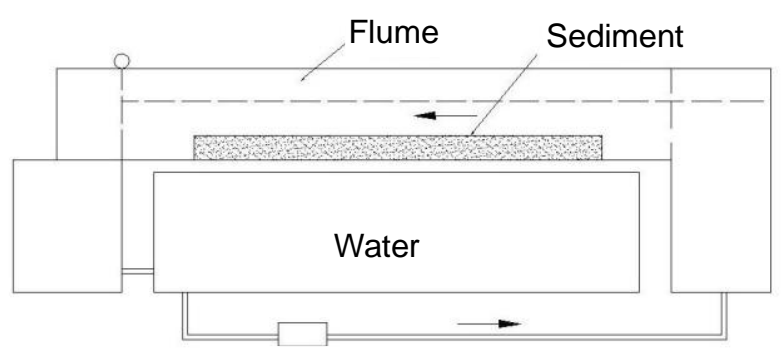

Pump

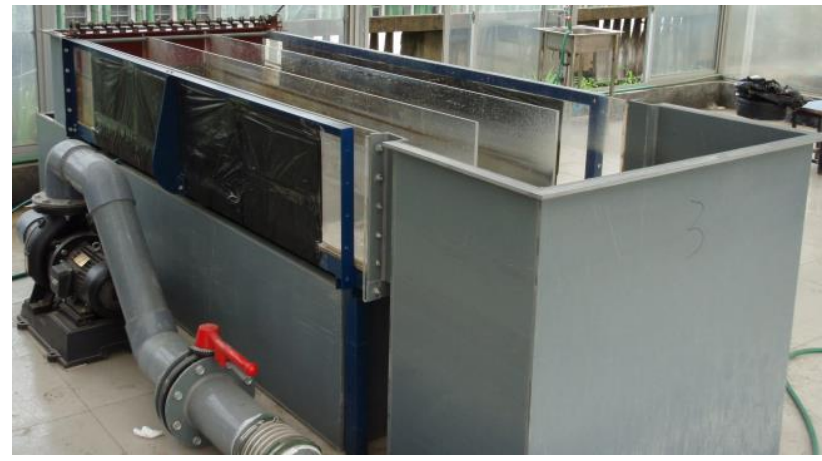

Figure 1. Overview of the experimental setup in one treatment. Water in the lower reservoir is pumped into the right basin. Overflowing water is moved to the left basin through the flumes which contain the experimental sediment/water interface. The hydrodynamic force comes from a water pump with a max flow of $100 \mathrm{~m}^{3} / \mathrm{h}$.

Table 1. Physicochemical Characteristics of Experimental Sediment

\begin{tabular}{llll}
\hline Sediment characteristics & \multicolumn{3}{c}{ Heavy metals } \\
\hline $\mathrm{pH}$ & $7.1 \pm 0.4$ & $\mathrm{Cd}(\mu \mathrm{g} / \mathrm{g} \mathrm{dw})$ & $0.42 \pm 0.04$ \\
$\mathrm{Eh}(\mathrm{mv})$ & $101 \pm 10$ & $\mathrm{~Pb}(\mu \mathrm{g} / \mathrm{g} \mathrm{dw})$ & $23 \pm 1$ \\
$\mathrm{CEC}(\mathrm{cmol} / \mathrm{kg})$ & $0.96 \pm 0.05$ & $\mathrm{Cu}(\mu \mathrm{g} / \mathrm{g} \mathrm{dw})$ & $23 \pm 0.2$ \\
$\mathrm{EC}(\mathrm{mS} / \mathrm{m})$ & $137 \pm 2$ & $\mathrm{Cr}(\mu \mathrm{g} / \mathrm{g} \mathrm{dw})$ & $69 \pm 1$ \\
$\mathrm{AVS}(\mu \mathrm{mol} / \mathrm{g} \mathrm{dw})$ & $8.9 \pm 1.2$ & $\mathrm{Ni}(\mu \mathrm{g} / \mathrm{g} \mathrm{dw})$ & $37 \pm 2$ \\
TOC $(\%)$ & $0.53 \pm 0.02$ & $\mathrm{Zn}(\mu \mathrm{g} / \mathrm{g} \mathrm{dw})$ & $23 \pm 0.1$ \\
Clay $(\%)$ & $6.3 \pm 0.3$ & $\mathrm{Fe}(\mathrm{mg} / \mathrm{g} \mathrm{dw})$ & $0.79 \pm 0.01$ \\
Moisture content $(\%)$ & $35 \pm 2$ & $\mathrm{Mn}(\mathrm{mg} / \mathrm{g} \mathrm{dw})$ & \\
\hline
\end{tabular}

${ }^{*}$ Average values $(\mathrm{n}=3)$ and standard deviations are presented

${ }^{* *}$ The average \pm standard deviation values $(n \geq 3)$ were calculated

However, changes in the control group were barely detectable (Figure 2). A significant increase in these values was observed in both treatment groups, but Eh increased faster in the $14 \mathrm{~cm} / \mathrm{s}$ treatment group than in the $3.2 \mathrm{~cm} / \mathrm{s}$ treatment group. These increases were approximately 2.0 and 1.5 times more than those for the control group, respectively. The TOC concentration decreased significantly in both treatment groups after 23 days, by approximately 26 and $25 \%$, respectively. AVS showed changes similar to those observed in TOC with decreases of approximately 40 and $33 \%$ in the 14 and $3.2 \mathrm{~cm} / \mathrm{s}$ treatment groups, respectively, but there was a decrease of only $8.7 \%$ in the control group.

In general, the concentrations of total heavy metals bound to the sediment changed only slightly. However, decreases in the surface sediment layer were observed in both treatment groups (Figure 2). The concentrations of all of the heavy metals in the $14 \mathrm{~cm} / \mathrm{s}$ treatment group decreased more than in the 3.2 $\mathrm{cm} / \mathrm{s}$ treatment group. Cd was found to be the most readily released metal from the sediment. Cd showed an $18 \%$ decrease in the $14 \mathrm{~cm} / \mathrm{s}$ group and a $6.5 \%$ decrease in the $3 \mathrm{~cm} / \mathrm{s}$ group. $\mathrm{Cd}$ release was followed by $\mathrm{Pb}, \mathrm{Mn}, \mathrm{Fe}, \mathrm{Cu}, \mathrm{Ni}, \mathrm{Cr}$, and $\mathrm{Zn}$ release in the $14 \mathrm{~cm} / \mathrm{s}$ treatment group.

\subsection{Release of Suspended Solids}

Turbidity and the concentration of total suspended solids (TSS) were both measured during the experiment. A significant difference between the treatments was found (Figure 3).
Rapid increases in turbidity and TSS were observed in the 14 $\mathrm{cm} / \mathrm{s}$ treatment group, and slight increases were observed in the $3.2 \mathrm{~cm} / \mathrm{s}$ treatment group. After 10 days, maximum values of $887 \mathrm{NTU}$ and $1311 \mathrm{mg} / \mathrm{L}$ were reached in the $14 \mathrm{~cm} / \mathrm{s}$ treatment. Afterward, they remained constant approximately 860 NTU and $1200 \mathrm{mg} / \mathrm{L}$. On day 6, maximum values of $171 \mathrm{NTU}$ and $287 \mathrm{mg} / \mathrm{L}$ were recorded in the $3 \mathrm{~cm} / \mathrm{s}$ group, and afterward they remained constant at approximately 130 NTU and $180 \mathrm{mg} / \mathrm{L}$. Changes were barely visible in the control group. A significant positive correlation was found between turbidity and TSS $\left(r^{2}=0.99, n=19\right)$ TSS $(\mathrm{mg} / \mathrm{L})=1.42 *$ turbidity (NTU).

The concentrations of clay, silt, and sand in the surface water were detected and calculated (Figure 4). A rapid increase in clay concentration was observed in the $14 \mathrm{~cm} / \mathrm{s}$ treatment group. After 10 days, the value remained constant at approximately $700 \mathrm{mg} / \mathrm{L}$. The maximum value of clay of $82 \mathrm{mg} / \mathrm{L}$ was reached after six days in the $3 \mathrm{~cm} / \mathrm{s}$ treatment group, after which a slight fluctuation was observed. A more rapid increase in silt was observed in the $14 \mathrm{~cm} / \mathrm{s}$ treatment group. After 10 days, the maximum value of silt was reached with $516 \mathrm{mg} / \mathrm{L}$, and then decreased slowly to $365 \mathrm{mg} / \mathrm{L}$ by day 23 . Similar changes in silt concentration were observed in the $3.2 \mathrm{~cm} / \mathrm{s}$ treatment group. The maximum value, $159 \mathrm{mg} / \mathrm{L}$, was reached after six days, and the lowest value of $68 \mathrm{mg} / \mathrm{L}$ was reached at day 23 . The sand concentrations were smaller and the changes were more acute. The maximum value was $82 \mathrm{mg} / \mathrm{L}$ in the $14 \mathrm{~cm} / \mathrm{s}$ treatment group, and sand concentration decreased to almost 0 

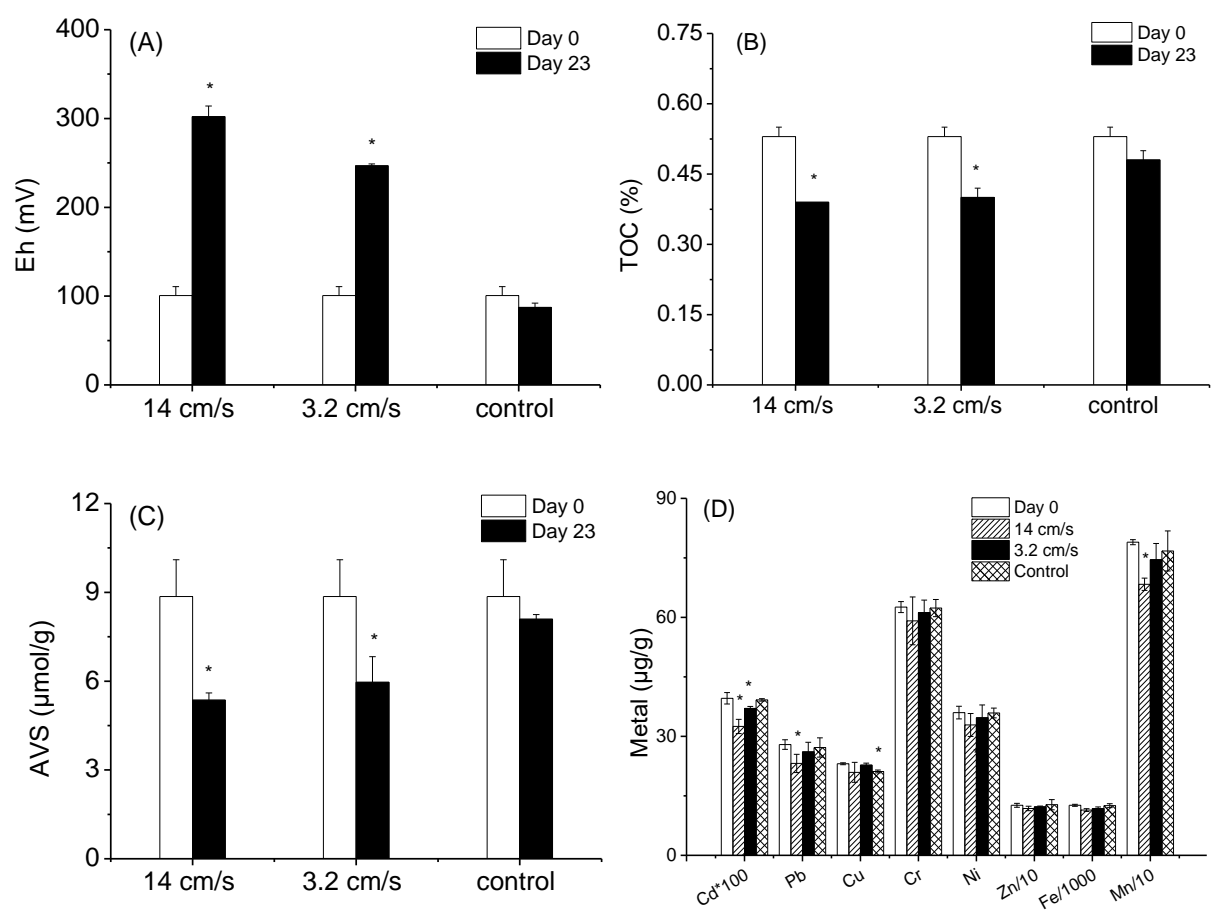

Figure 2. Variations in Eh, TOC, AVS, and metal concentrations in the surface sediment over time. Initial concentrations (day 0 ) and final concentrations (day 23) of each group are shown. Average concentrations $(\mathrm{n}=3)$ and standard deviations are presented.
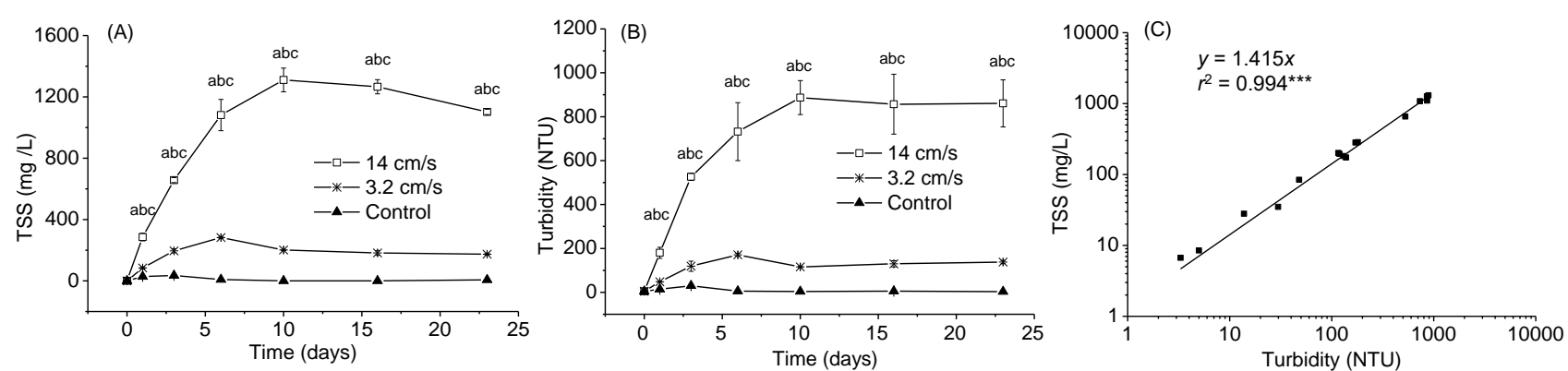

Figure 3. Turbidity and TSS in the surface water of all groups as a function of time. Where relationships are significant, $r^{2}$ is given.

by the end of the experiment.

Significant differences in the suspended concentrations of solid metals, except $\mathrm{Zn}$, were noticed between treatments. Concentrations of $\mathrm{Cd}, \mathrm{Pb}, \mathrm{Cu}, \mathrm{Cr}, \mathrm{Ni}, \mathrm{Fe}$, and $\mathrm{Mn}$ were higher in the $14 \mathrm{~cm} / \mathrm{s}$ treatment group than in the $3 \mathrm{~cm} / \mathrm{s}$ treatment group. Obvious increases in the concentrations of all metals were observed in the $14 \mathrm{~cm} / \mathrm{s}$ treatment group, and increases in the concentrations of $\mathrm{Zn}$ and $\mathrm{Pb}$ were observed in the $3 \mathrm{~cm} / \mathrm{s}$ treatment group. The loading plots of the principle component analysis (PCA) in the suspended solid samples are shown in Figure 5. Metals and several physicochemical parameters of suspended solids were involved in this analysis. Component 1 (Comp. 1) was found to explain $48 \%$ of the total variance. Comp. 1 showed high loadings on suspended solids and trace metals other than Zn. Component 2 (Comp. 2) was found to explain $26 \%$ of the total variance. It showed high loading with respect to the physicochemical parameters in surface water.

\subsection{Filterable Heavy Metals in the Surface Water}

Significant differences in filterable metal concentrations were noticed in all three groups. Concentrations of $\mathrm{Cd}, \mathrm{Pb}, \mathrm{Cu}$, $\mathrm{Cr}, \mathrm{Ni}, \mathrm{Fe}$, and $\mathrm{Mn}$ in the $14 \mathrm{~cm} / \mathrm{s}$ treatment group were higher than in the $3 \mathrm{~cm} / \mathrm{s}$ treatment group. Concentrations of filterable heavy metals other than $\mathrm{Zn}$ in surface water increased significantly over time in the $14 \mathrm{~cm} / \mathrm{s}$ treatment group and increased slightly over time in the $3.2 \mathrm{~cm} / \mathrm{s}$ treatment group (Figure 6). After 23 days $\mathrm{Cd}, \mathrm{Pb}, \mathrm{Cu}, \mathrm{Cr}, \mathrm{Ni}, \mathrm{Fe}$ and $\mathrm{Mn}$ increased by a factor of $21,10,13,3.6,3.7,11$ and 7.2 in the $14 \mathrm{~cm} / \mathrm{s}$ group 

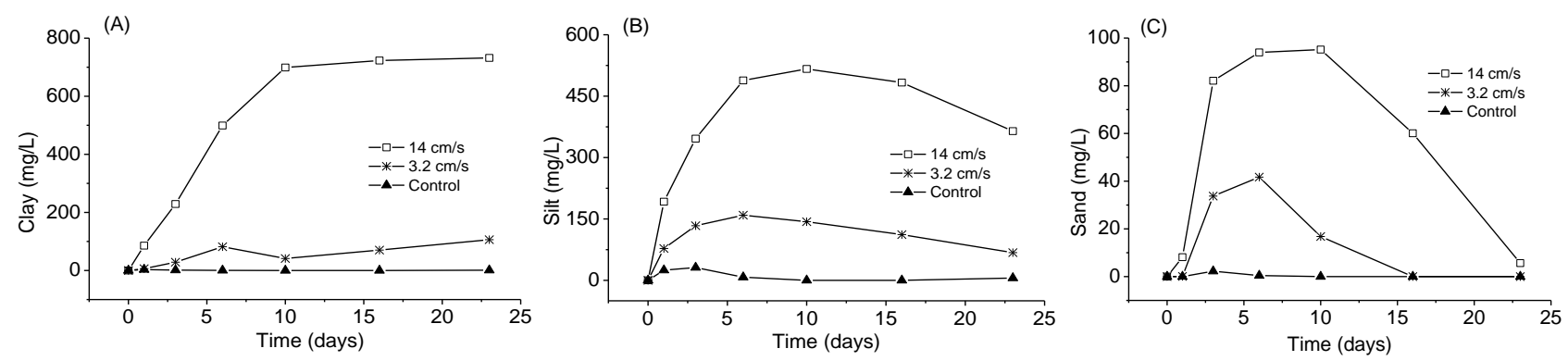

Figure 4. Clay $(<3.9 \mu \mathrm{m})$, silt $(3.9 \sim 63 \mu \mathrm{m})$ and sand $(63 \sim 2000 \mu \mathrm{m})$ concentrations in the surface water of all groups as a function of time.
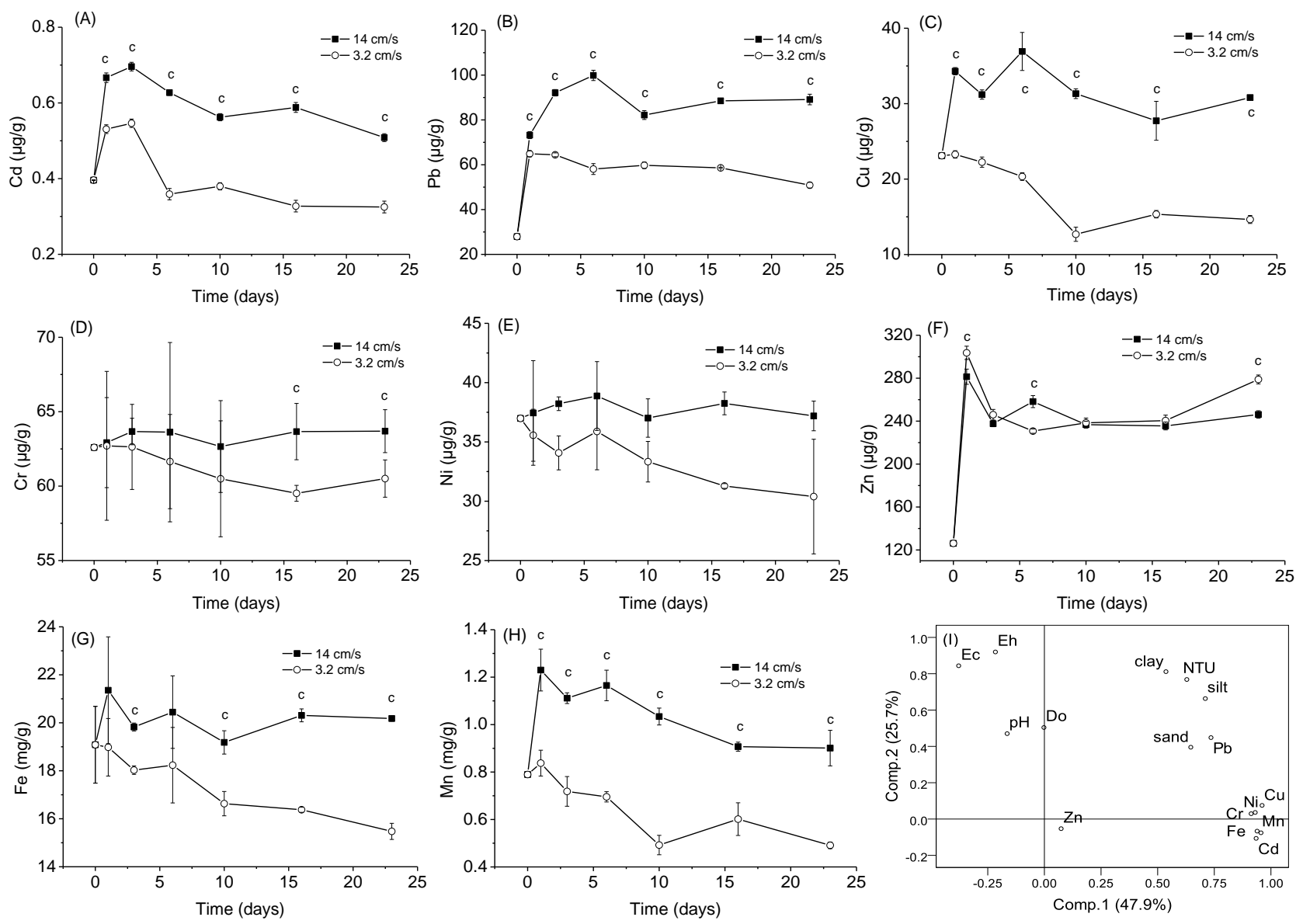

Figure 5. Concentrations of heavy metals bound to TSS in the surface water of both treatment groups as a function of time and loading plot of principle component analysis (PCA) of suspended heavy metal concentrations.

and $4.1,1.7,1.8,1.7,1.5,4.7$ and 0.12 in the $3 \mathrm{~cm} / \mathrm{s}$ group, respectively. The concentration of $\mathrm{Zn}$ decreased by $67 \%$ in the $14 \mathrm{~cm} / \mathrm{s}$ treatment group and by $88 \%$ in the $3 \mathrm{~cm} / \mathrm{s}$ treatment group. In the control group, $\mathrm{Pb}, \mathrm{Cu}, \mathrm{Zn}$, and $\mathrm{Mn}$ decreased by 42, 23, 96 and 85\%, respectively, and $\mathrm{Cd}, \mathrm{Cr}$, Ni and Fe increased by 86, 94, 86 and 146\%, respectively, after 23 days. Filterable metals and suspended solids were involved in PCA. Component 1 (Comp. 1) was found to explain 59\% of the total variance. It showed high loadings on TSS and trace metals oth- er than Zn.

\subsection{Evaluation of the Metal Transportations}

The data regarding the transportation of all heavy metals except $\mathrm{Zn}$ from the sediment to filterable phases in water are consistent with Equation (1):

$C=C_{0} \times\left(1-\exp \left(-K_{t} \times T\right)\right)$ 

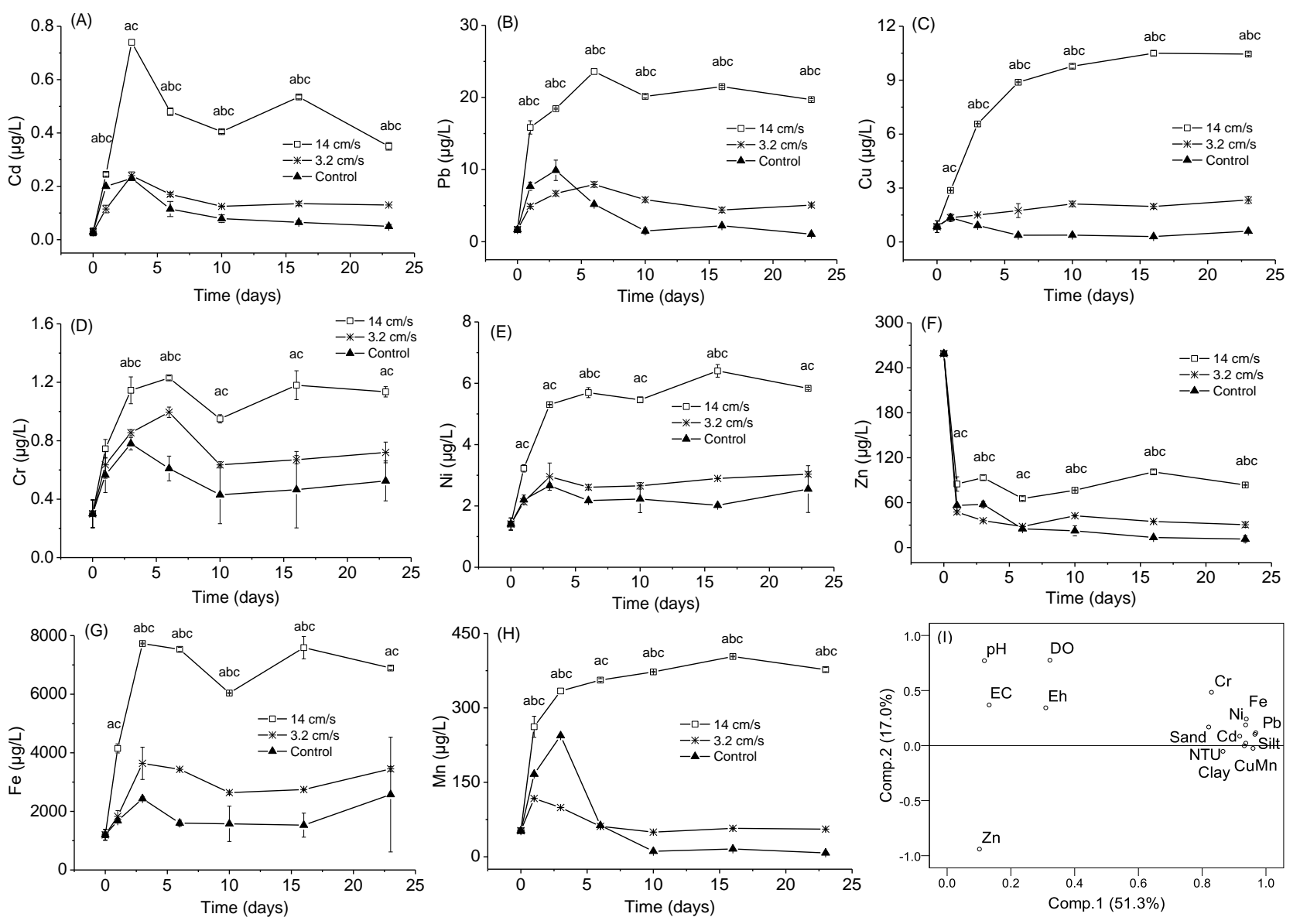

Figure 6. Filterable heavy metal concentrations in the surface water of all groups as a function of time and loading plot of principle component analysis (PCA) of filterable heavy metals.

Table 2. The Final Heavy Metal Concentrations $\left(C_{0}\right)$ in Filterable Phase, Transport Coefficients $\left(K_{t}\right)$ for Heavy Metals, and Adjusted Significant Relationships (Adj. $r^{2}$ ) of both Treatments, $n=7$

\begin{tabular}{lllllll}
\hline Treatment & \multicolumn{3}{c}{$14 \mathrm{~cm} / \mathrm{s}$} & \multicolumn{3}{c}{$3.2 \mathrm{~cm} / \mathrm{s}$} \\
\hline Parameter & $\mathrm{C}_{0}$ & $\mathrm{~K}_{\mathrm{t}}$ & Adj. $\mathrm{r}^{2}$ & $\mathrm{C}_{0}$ & $\mathrm{~K}_{\mathrm{t}}$ & Adj. $^{2}$ \\
\hline $\mathrm{Cd}$ & $0.49 \pm 0.07$ & $1.1 \pm 0.9$ & $0.57^{* * *}$ & $0.16 \pm 0.02$ & $1.6 \pm 1.5$ & $0.21^{*}$ \\
$\mathrm{~Pb}$ & $21 \pm 1$ & $1.4 \pm 0.4$ & $0.94^{* * *}$ & $6.0 \pm 0.7$ & $1.8 \pm 1.6$ & $0.46^{* * *}$ \\
$\mathrm{Cu}$ & $10 \pm 0.3$ & $0.32 \pm 0.03$ & $0.99^{* * *}$ & $2.0 \pm 0.2$ & $0.84 \pm 0.52$ & $0.17^{* * *}$ \\
$\mathrm{Cr}$ & $1.1 \pm 0.1$ & $1.1 \pm 0.5$ & $0.75^{* * *}$ & $0.77 \pm 0.09$ & $1.8 \pm 1.6$ & $0.23^{* * *}$ \\
$\mathrm{Ni}$ & $5.9 \pm 0.4$ & $0.79 \pm 0.25$ & $0.85^{* * *}$ & $2.8 \pm 0.3$ & $1.4 \pm 1.0$ & $-0.28^{* * *}$ \\
$\mathrm{Fe}$ & $7170 \pm 430$ & $1.0 \pm 0.4$ & $0.86^{* * *}$ & $3180 \pm 340$ & $1.1 \pm 0.7$ & $0.41^{* * *}$ \\
$\mathrm{Mn}$ & $372 \pm 15$ & $1.1 \pm 0.3$ & $0.94^{* * *}$ & $74 \pm 15$ & $1.4 \mathrm{E}+07$ & $-0.87^{*}$ \\
\hline
\end{tabular}

${ }^{*} \mathrm{p}<0.05,{ }^{* *} \mathrm{p}<0.01,{ }^{* * *} \mathrm{p}<0.001,{ }^{* * * *}$ Average values $(n=3)$ and standard deviations are presented

Here, $C$ is the concentration of each metal in the filterable phase $(\mu \mathrm{g} / \mathrm{L})$ in water as a function of time. $C_{0}$ stands for the final stable heavy metal concentration in the filterable phase $(\mu \mathrm{g} / \mathrm{L})$ in water. $K_{t}$ is the coefficient of the rate of transportation of heavy metal from the sediment to the filterable phase in water. $T$ is the time in days. In this study, the fitted curves for heavy metal transportation are shown in Figure 7, and the final heavy metal concentrations in the filterable phase and transport coefficients for heavy metals and significant relationships $\left(r^{2}\right)$ were calculated (Table 2).

The data regarding the heavy metal concentrations in the $14 \mathrm{~cm} / \mathrm{s}$ treatment group were consistent with Equation (1) with significant relationships $\left(r^{2}\right)$ of $0.57 \sim 0.99$. As shown in Table 2, the $K_{t}$ values of the metals appeared in the following order: $\mathrm{Pb}>\mathrm{Mn}>\mathrm{Cr}>\mathrm{Cd}>\mathrm{Fe}>\mathrm{Ni}>\mathrm{Cu}$. The data regarding the heavy metal concentrations in the $3.2 \mathrm{~cm} / \mathrm{s}$ treatment group appeared in a similar order: $\mathrm{Mn}>\mathrm{Pb}>\mathrm{Cr}>\mathrm{Cd}>\mathrm{Ni}>$ $\mathrm{Fe}>\mathrm{Cu}$. The final filterable metal concentrations in water in 
the $14 \mathrm{~cm} / \mathrm{s}$ treatment group were higher than in the $3.2 \mathrm{~cm} / \mathrm{s}$ treatment group, but the transport rates were lower.

The distribution between filterable heavy metals in surface water and total metals in sediment after 23 days is given by the balance coefficient $\left(K_{B}\right)$ as shown in Equation (2):

$K_{B}=C_{W} / C_{S}$

Here $C_{W}$ stands for the final heavy metal concentration in the filterable phase (ug/L) and $\mathrm{C}_{S}$ is the concentration in sediment $(\mu \mathrm{g} / \mathrm{g})$.

The $K_{B}$ values of all metals increased visibly with the flow speed (Figure 8 ). The $\mathrm{K}_{\mathrm{B}}$ values of the metals appeared to be in the following order in the $14 \mathrm{~cm} / \mathrm{s}$ treatment group: $\mathrm{Cd}>$ $\mathrm{Pb}>\mathrm{Zn}>\mathrm{Fe}>\mathrm{Mn}>\mathrm{Cu}>\mathrm{Ni}>\mathrm{Cr}$. The order was similar in the $3.2 \mathrm{~cm} / \mathrm{s}$ and control groups. The contribution of hydrodynamic conditions in the $14 \mathrm{~cm} / \mathrm{s}$ treatment to the $\mathrm{Mn} K_{B}$ value was $5382 \%$ higher than in the control group and was also higher for $\mathrm{Pb}(1930 \%), \mathrm{Cu}$ (1754\%), Cd (1182\%), Zn (758\%), $\mathrm{Fe}(500 \%), \mathrm{Ni}(251 \%)$ and $\mathrm{Cr}(235 \%)$. The contribution of hydrodynamic conditions in the $3.2 \mathrm{~cm} / \mathrm{s}$ treatment to the $\mathrm{Mn} K_{B}$
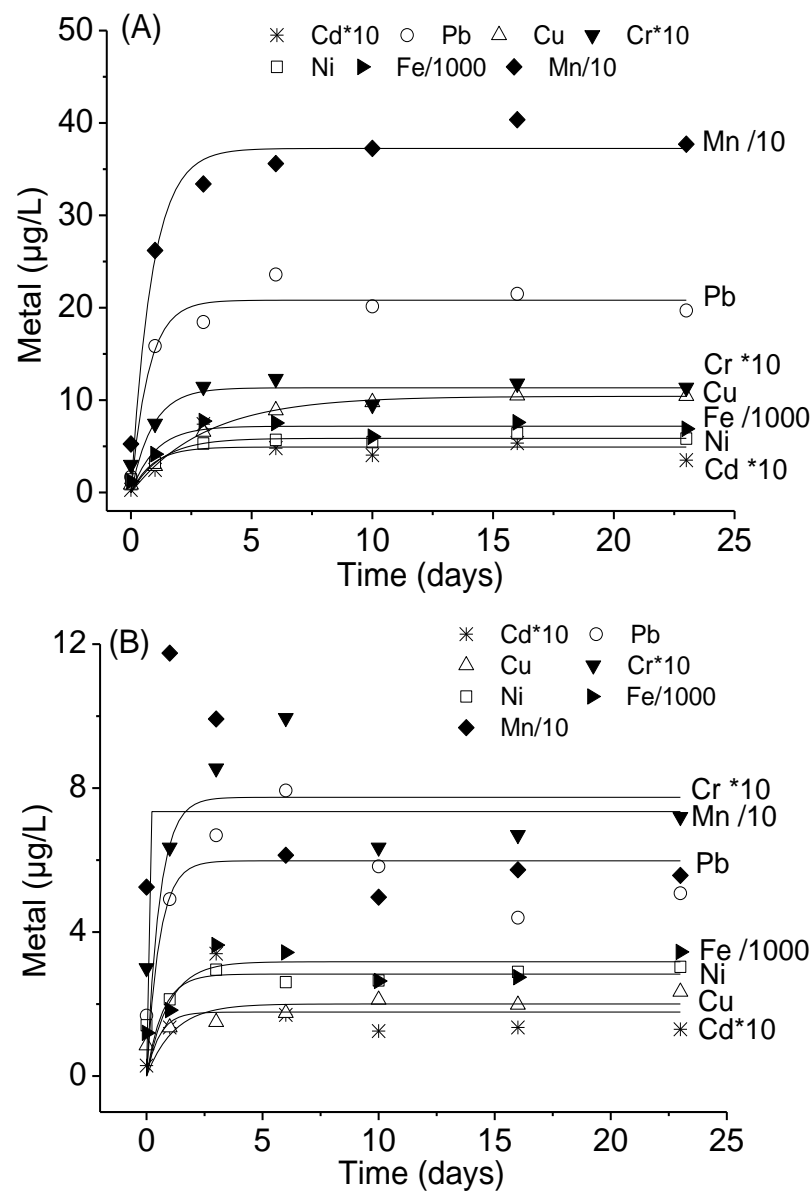

Figure 7. Fitted curves for heavy metal transportation from the sediment to filterable phases in water for both treatments. values relative to the control group was $639 \%$ and was also higher for $\mathrm{Pb}(461 \%), \mathrm{Cu}$ (363\%), $\mathrm{Zn}(280 \%), \mathrm{Cd}(275 \%), \mathrm{Fe}$ (233\%), Cr (140\%), and $\mathrm{Ni}(134 \%)$.

The partitioning of heavy metals between filterable and particulate phases is also given by the distribution coefficient $\left(\mathrm{K}_{\mathrm{D}}\right)$ (Fan et al., 2007) as shown in Equation (3):

$K_{D}=C_{P} / C_{W}$

Here $C_{P}$ is the concentration in a particulate phase $(\mu \mathrm{g} / \mathrm{kg})$. The $K_{D}$ values of heavy metals increased as the velocity increased during the experiments (Figure 8). For the heavy metals investigated, the partitioning coefficients were found to be in the order of $\mathrm{Cr}>\mathrm{Ni}>\mathrm{Pb}>\mathrm{Zn}>\mathrm{Cu}>\mathrm{Fe}>\mathrm{Mn}>\mathrm{Cd}$ in the $14 \mathrm{~cm} / \mathrm{s}$ treatment group, and a similar order $(\mathrm{Cr}>\mathrm{Ni}>\mathrm{Pb}>\mathrm{Zn}>$ $\mathrm{Cu}>\mathrm{Mn}>\mathrm{Fe}>\mathrm{Cd}$ ) was observed in the $3.2 \mathrm{~cm} / \mathrm{s}$ treatment group.

\section{Discussion}

The process of heavy metal release is complicated. The release of metal occurs immediately after sediments are disturbed. Slower reactions continuing on particles of sediment that remain suspended result in solute release in the surrounding fluid (Kalnejais et al., 2010). During this process, particles can aggregate into flocs relatively quickly and precipitate from the water much more rapidly than individual particles (Jackson and Burd, 1998; Olsen et al., 1982). Finally, the distribution of metals reaches a balance. In the present study, hydrodynamic forces increased sediment Eh and decreased sediment TOC. A significant increase of Eh for both treatments was noticed. This increase was 2.0 times greater in the $14 \mathrm{~cm} / \mathrm{s}$ group and 1.5 times greater in the $3 \mathrm{~cm} / \mathrm{s}$ treatment group after 23 days. However, after 23 days the TOC concentration decreased by approximately 26 and 25\%, respectively, and AVS decreased by approximately 40 and $33 \%$, respectively. Hydrodynamic forces can dramatically change the surface water geochemistry. The dissolved oxygen in surface water increases followed by sediment geochemistry changes, including Eh. The findings regarding Eh in sediment are consistent with research showing that an influx of dissolved oxygen causes a positive change in sediment Eh (De Jonge et al., 2012; Eggleton and Thomas, 2004). AVS can form thermodynamically stable metal-sulfide precipitates that decrease the concentration of metal ions in the sediment pore water and thereby reduce metal bioavailability (De Jonge et al., 2012). The precipitates are consumed during the process, which may lead to the release of heavy metals (Stone and Droppo, 1996). In the present study, Cd was found to be readily released from the sediment, followed by $\mathrm{Pb}, \mathrm{Mn}, \mathrm{Fe}$, $\mathrm{Cu}, \mathrm{Ni}, \mathrm{Cr}$ and $\mathrm{Zn}$, in that order. Each type of metal has differrent characteristics during the release process (Caille et al., 2003; Eggleton and Thomas, 2004; Mattiuzzo et al., 2007). Previous studies have demonstrated that $\mathrm{Pb}$ and $\mathrm{Cu}$ are released more rapidly than $\mathrm{Zn}$ (Caille et al., 2003). Cd appeared most easily interchangeable, whereas $\mathrm{Cr}$ appeared to be the most different in the surface sediment samples of the Bahía Blanca estuary (Alvarez et al., 2011). 

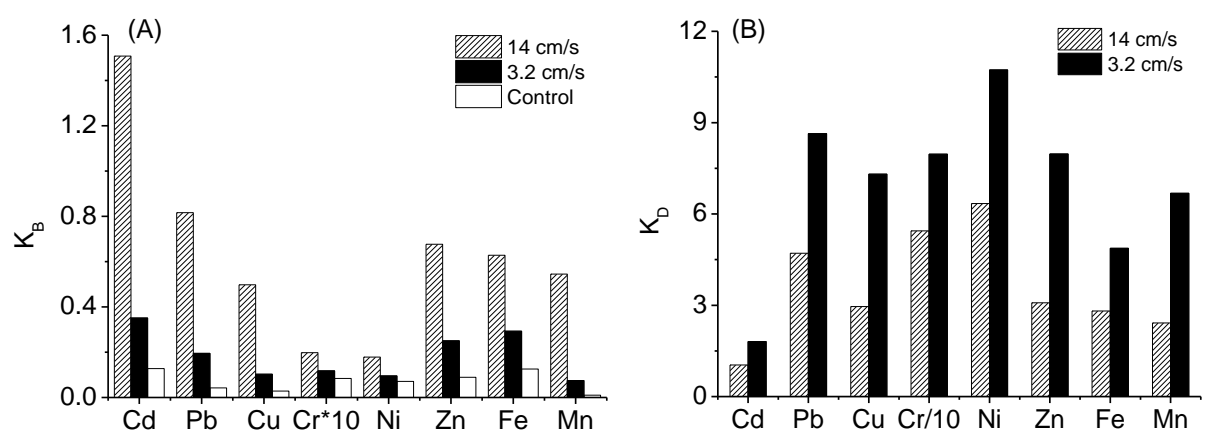

Figure 8. The balance coefficients $\left(\mathrm{K}_{\mathrm{B}}\right)$ between filterable metal concentrations in surface water and total metal concentrations in sediment for all three groups and distribution coefficients $\left(\mathrm{K}_{\mathrm{D}}\right)$ between filterable and particulate phases in surface water in the two treatment groups.

Particles in surface sediment were rushed into the water when water flow was included and the amount of the particles increased as the speed of the flow increased. Turbidity and TSS increased from just above 0 to $860 \mathrm{NTU}$ and $1200 \mathrm{mg} / \mathrm{L}$ in the $14 \mathrm{~cm} / \mathrm{s}$ treatment group, which was markedly larger than in the $3 \mathrm{~cm} / \mathrm{s}$ treatment group. A significant positive correlation was observed between turbidity and TSS $\left(r^{2}=0.991, n=19\right)$ : TSS $(\mathrm{mg} / \mathrm{L})=1.42 *$ turbidity $(\mathrm{NTU})$. Correlations between TSS and turbidity may depend on location, geology, and features of the landscape (Rügner et al., 2013). For conditions commonly observed in natural rivers, a linear or nearly linear relationship between NTU and TSS with slopes of $1 \sim 2.5$ may be expected (Loperfido et al., 2010; Uhrich and Bragg, 2000). Values for the TSS/turbidity ratio are within the range of 0.9 (Ammer springs) and 2.4 (Echaz River) in southwestern Germany (Rügner et al., 2013). We found that the bigger the particles were, the less they suspended and the faster they settled to the sediment. Clay, however, could remain suspended. Heavy metals and other contaminants are released into the water with particles, especially clay. $\mathrm{Cd}, \mathrm{Cu}, \mathrm{Cr}, \mathrm{Pb}$, and $\mathrm{Zn}$ display pronounced correlations with relative clay content (Dou et al., 2013). This indicates that fine particles are important carriers of trace metals. This was also observed in resuspension/oxidation experiments of anoxic sediments and is attributed to translocation (re-adsorption or coprecipitation) of heavy metals onto more soluble solid phases such as carbonates, ferric hydroxides and clay minerals (Calmano et al., 1993; Förstner, 1995; Stephens et al., 2001). That is because clay tends to bind with high quantity organic matter, such as humic and fulvic acids, colloids, and synthetic organic substances. Large amounts of heavy metals are associated with these types of organic matter (Förstner and Wittmann, 1979; Jain et al., 2005; Uluturhan et al., 2011). Dou et al. (2013) indicated that $\mathrm{Zn}, \mathrm{Cr}, \mathrm{Pb}$, $\mathrm{Cd}$ and partly $\mathrm{Cu}$ have a strong correlations with organic matter. This can also explain the reduced heavy metal concentrations with reduced TOC concentrations in sediment. $K_{D}$ was calculated and used to indicate each element's affinity to a particulate phase. In this study, the magnitudes of the affinity were found to be in this order: $\mathrm{Cr}>\mathrm{Ni}>\mathrm{Pb}>\mathrm{Zn}>\mathrm{Cu}>\mathrm{Fe}>\mathrm{Mn}>$ $\mathrm{Cd}$. This suggests that $\mathrm{Cr}$ is the metal most strongly bound by TSS and that Cd is the least partitioned metal in this phase. This is generally consistent with the Irving-Williams rule: $\mathrm{Cu}^{2+}>$ $\mathrm{Ni}^{2+}>\mathrm{Pb}^{2+}>\mathrm{Co}^{2+}>\mathrm{Zn}^{2+}>\mathrm{Cd}^{2+}>\mathrm{Fe}^{2+}>\mathrm{Mn}^{2+}>\mathrm{Mg}^{2+}>\mathrm{Ca}^{2+}$ (Jiang et al., 2001), which used to explain the stability of different metal-organic complexes from laboratory experiments and stability sequences observed in natural waters (Cantwell et al., 2002; Guo et al., 2000). Only $\mathrm{Cu}$ and $\mathrm{Cd}$ were at different positions, probably because of the complexity of ligands in the sediment. Previous studies have reported nearly the same order: $\mathrm{Pb}>\mathrm{Cr}>\mathrm{Zn}>\mathrm{Cu}>\mathrm{Cd}>\mathrm{Ni}$ (Zheng et al., 2012), with $\mathrm{Ni}$ at a different position compared to our results. The $K_{D}$ values of $\mathrm{Ni}$ in the study of Couceiro et al. (2009) are $7.7 \sim 17$ after $8 \mathrm{~h}$ under hydrodynamic conditions of $50 \mathrm{~cm} / \mathrm{s}$, similar to our results. $\mathrm{Cr}$ is much less mobile. $\mathrm{Cr}(\mathrm{VI})$ is easily reduced to $\mathrm{Cr}$ (III) with the presence of organic matter and then bound to organic matter in aquatic environments (Cervantes et al., 2001). The $K_{D}$ values of $\mathrm{Cr}$ on the eastern side of the Qatari peninsula are $16 \sim 63$ (Dahab and Al-Madfa, 1997), which are close to our results. The PCA of suspended heavy metal concentrations suggests that the mobility of metals, especially $\mathrm{Pb}$, may be associated with the suspended solids in the surface water. $\mathrm{Pb}$ was demonstrated to be easily adsorbed by particles (Wang et al., 2012).

The amount of filterable metals released from sediment into the surface water increased over time. Faster flow promoted the release of metals. The concentrations of heavy metals, except $\mathrm{Zn}$, were closely correlated with the fine particle concentration according to the PCA analysis. The results tentatively suggest that the filterable phase of metals may contain small materials, such as colloidal fractions, which can pass through filter membranes with metals adsorbed in them. The same speculation was put forward by two previous studies (Huang et al., 2012; Kalnejais et al., 2010). The researchers used a polycarbonate $0.015 \mu \mathrm{m}$ filter (Nucleopore) to filter colloidal fractions. In the present work, the colloidal metal and the dissolved metal in surface water were studied together for their biological toxicity. The transportation rates of each metal from the sediment to the filterable phases in water were different. The concentrations of all filterable heavy metals, except $\mathrm{Zn}$, were consistent with Equation (1), and the rates of transportation were found to be in the following order: $\mathrm{Pb}>$ $\mathrm{Mn}>\mathrm{Cr}>\mathrm{Cd}>\mathrm{Fe}>\mathrm{Ni}>\mathrm{Cu}$. $\mathrm{Pb}$ requires the maximum len- 
gth of time to reach equilibrium, whereas $\mathrm{Cu}$ requires the minimum length. Zn concentration in the tap water was higher than in Taihu Lake because of its galvanized service pipes. The filtered surface $\mathrm{Zn}$ concentration was high at day 0 , then the extra $\mathrm{Zn}$ rapidly adsorbed to the suspended solids and the sediment.

The $K_{B}$ value was calculated to indicate each element's ability to exit the solid phase when the system reached a balance. The $K_{B}$ value of Cd was the largest in the three groups, which shows that $\mathrm{Cd}$ tends to be desorbed more easily than other metals. This means that $\mathrm{Cd}$ may be relatively enriched in the dissolved phase despite only moderate sediment contamination (Bryan and Langston, 1992; Shine et al., 1998). Once released from particulates, $\mathrm{Cd}$ tends to remain in the dissolved state longer than other metals (Caetano et al., 2003). Caille et al. (2003) found $\mathrm{Cu}$ to be continuously released in solution during the experiments. The $K_{B}$ values of Mn were higher in the $14 \mathrm{~cm} / \mathrm{s}$ and $3.2 \mathrm{~cm} / \mathrm{s}$ treatment groups than in the control group. This was the largest difference in the study. This shows that $\mathrm{Mn}$ is more easily affected by flow speed than other metals.

\section{Conclusions}

Durative hydrodynamic forces decreased sediment TOC but increased sediment Eh and the amount of suspended solids in water. Because of these changes, metals were released from the sediment to the surface water in the form of a particulate and a filterable phase. The faster the water flowed, the more pronounced the changes and the more metals were released. Larger particles were suspended less and settled to the sediment faster during the process. Fine particles, clay for example, are important carriers of trace metals from sediment to the surface water. The amount of filterable phase metal was also significantly correlated with fine particles. This indicated that many small materials rich in metals that could pass through the filter membrane, such as colloidal fractions, were suspended in the surface water with other particles.

$\mathrm{Cr}$ is the metal that is most strongly bound to suspended solids and $\mathrm{Cd}$ is the least partitioned metal in the particulate phase. This is consistent with the order of the balance coefficient, which also suggests that $\mathrm{Cd}$ is desorbed more easily than other metals. $\mathrm{Pb}$ was found to take the least time to reach a balance between a solid and dissolved state, and $\mathrm{Cu}$ was found to take the longest. The release of $\mathrm{Mn}$ was found to be the most readily affected by flow speed, followed by $\mathrm{Pb}, \mathrm{Cu}, \mathrm{Cd}$, $\mathrm{Zn}, \mathrm{Fe}, \mathrm{Ni}$, and $\mathrm{Cr}$, in that order. The results of the present work indicate that hydrodynamic conditions can dramatically enhance the mobility of metals, which may result in the release of sediment-bound metals to the surface water, and different metals show different characteristics during the release.

Acknowledgments: We are grateful for grants from National Science Fund for Distinguished Young Scholars (No. 51225901), National Science Funds for Creative Research Groups of China (No. 51421006), the Outstanding Youth Fund of Jiangsu Province (No. BK2012037), Program for Changiiang Scholars and Innovative Re- search Team in University (No. IRT13061), the Key Program of National Natural Science Foundation of China (No. 41430751), the National Natural Science Foundation of China (No. 51479065) and PAPD.

\section{References}

Alvarez, M.B., Domini, C.E., Garrido, M., Lista, A.G., and Fernández-Band, B.S. (2011). Single-step chemical extraction procedures and chemometrics for assessment of heavy metal behaviour in sediment samples from the Bahía Blanca estuary, Argentina. $J$. Soils Sed., 11(4), 657-666. http://dx.doi.org/10.1007/s11368-0110350-7

Authority, T.B. (2000). Atlas of Ecology and Environment of The Taihu Lake, Science Press, Beijing.

Bryan, G.W., and Langston, W.J. (1992). Bioavailability, accumulation and effects of heavy metals in sediments with special reference to United Kingdom estuaries: A review. Environ. Pollut., 76(2), 89131. http://dx.doi.org/10.1016/0269-7491(92)90099-V

Caetano, M., Madureira, M.J., and Vale, C. (2003). Metal remobilisation during resuspension of anoxic contaminated sediment: Shortterm laboratory study. Water Air Soil Pollut., 143(1-4), 23-40. http: //dx.doi.org/10.1023/A:1022877120813

Caille, N., Tiffreau, C., Leyval, C., and Morel, J.L. (2003). Solubility of metals in an anoxic sediment during prolonged aeration. Sci. Total Environ., 301(1-3), 239-250. http://dx.doi.org/10.1016/S00 48-9697(02)00289-9

Calmano, W., Förstner, U., and Hong, J. (1994). Mobilization and scavenging of heavy metals following resuspension of anoxic sediments from the Elbe River, in C.N. Alpers and D. Blowes (Eds.), Environmental Geochemistry of Sulfide Oxidation, American Chemical Society, pp. 298-321.

Calmano, W., Hong, J., and Forstner, U. (1993). Binding and mobilisation of heavy metals in contaminated sediments affected by $\mathrm{pH}$ and redox potential. Water Sci. Technol., 28(8-9), 223-235.

Campana, O., Blasco, J., and Simpson, S.L. (2013). Demonstrating the appropriateness of developing sediment quality guidelines based on sediment geochemical properties. Environ. Sci. Technol., 47(13), 7483-7489. http://dx.doi.org/10.1021/es4009272

Cantwell, M.G., Burgess, R.M., and Kester, D.R. (2002). Release and phase partitioning of metals from anoxic estuarine sediments during periods of simulated resuspension. Environ. Sci. Technol., 36(24), 5328-5334. http://dx.doi.org/10.1021/es0115058

Cantwell, M.G., Burgess, R.M., and King, J.W. (2008). Resuspension of contaminated field and formulated reference sediments Part I: Evaluation of metal release under controlled laboratory conditions. Chemosphere, 73(11), 1824-1831. http://dx.doi.org/10.1016/j.che mosphere.2008.08.007

Cervantes, C., Campos-García, J., Devars, S., Gutiérrez-Corona, F., Loza-Tavera, H., Torres-Guzmán, J.C., and Moreno-Sánchez, R. (2001). Interactions of chromium with microorganisms and plants. FEMS Microbiol. Rev., 25(3), 335-347. http://dx.doi.org/10.1111/j. 1574-6976.2001.tb00581.x

Couceiro, F., Rauen, W., Millward, G.E., Lin, B., Turner, A., and Falconer, R. (2009). Transport and reactivity of nickel in estuarine sediments: Results from a high capacity flume. Mar. Chem., 117 (1 - 4), 71-76. http://dx.doi.org/10.1016/j.marchem.2009.06.005

Dahab, O.A., and Al-Madfa, H. (1997). Chromium distribution in waters and sediments of the eastern side of The Qatari Peninsula. Sci. Total Environ., 196(1), 1-11. http://dx.doi.org/10.1016/S0048-969 7(96)05339-9

De Jonge, M., Teuchies, J., Meire, P., Blust, R., and Bervoets, L. (2012). The impact of increased oxygen conditions on metal-contaminated sediments part I: Effects on redox status, sediment geochemistry 
and metal bioavailability. Water Res., 46(7), 2205-2214. http://dx. doi.org/10.1016/j.watres.2012.01.052

Dou, Y., Li, J., Zhao, J., Hu, B., and Yang, S. (2013). Distribution, enrichment and source of heavy metals in surface sediments of the eastern Beibu Bay, South China Sea. Mar. Pollut. Bull., 67(1-2), 137-145. http://dx.doi.org/10.1016/j.marpolbul.2012.11.022

Eggleton, J., and Thomas, K.V. (2004). A review of factors affecting the release and bioavailability of contaminants during sediment disturbance events. Environ. Int., 30(7), 973-980. http://dx.doi.org/ 10.1016/j.envint.2004.03.001

Fan, Q., He, J., Xue, H., LÜ, C., Liang, Y., Saruli, Sun, Y., and Shen, L. (2007). Competitive adsorption, release and speciation of heavy metals in the Yellow River sediments, China. Environ. Geol., 53(2), 239-251. http://dx.doi.org/10.1007/s00254-007-0638-5

Förstner, U. (1995). Non-linear release of metals from aquatic sediments, in W. Salomon and W.M. Stigliani (Eds.), Biogeodynamics of Pollutants in Soils and Sediments, Risk Assessment of Delayed and Non-linear Responses, Environmental Science, Springer Berlin Heidelberg, pp. 247-307. http://dx.doi.org/10.1007/978-3-64279418-6_11

Förstner, U., and Wittmann, G.T.W. (1979). Metal Pollution in the Aquatic Environment, Springer Berlin Heidelberg. http://dx.doi.org /10.1007/978-3-642-96511-1

Gao, X., and Chen, C.T.A. (2012). Heavy metal pollution status in surface sediments of the coastal Bohai Bay. Water Res., 46(6), 1901-1911. http://dx.doi.org/10.1016/j.watres.2012.01.007

Guo, L., Santschi, P.H., and Warnken, K.W. (2000). Trace metal composition of colloidal organic material in marine environments. Mar. Chem., 70(4), 257-275. http://dx.doi.org/10.1016/S0304-4203 (00)00031-1

Huang, J.Z., Ge, X.P., Yang, X.F., Zheng, B., and Wang, D.S. (2012). Remobilization of heavy metals during the resuspension of Liangshui River sediments using an annular flume. Chin. Sci. Bull., 57(27), 3567-3572. http://dx.doi.org/10.1007/s11434-012-5370-1

Jackson, G.A., and Burd, A.B. (1998). Aggregation in the marine environment. Environ. Sci. Technol., 32(19), 2805-2814. http://dx. doi.org/10.1021/es980251w

Jain, C.K., Singhal, D.C., and Sharma, M.K. (2005). Metal pollution assessment of sediment and water in the River Hindon, India. Environ. Monit. Assess., 105(1-3), 193-207. http://dx.doi.org/10.100 7/s10661-005-3498-z

Jiang, J., Wang, G., and Fang, L. (2001). Complexation between soil water-soluble organic matter and heavy metal (in Chinese). Soil Environ. Sci., 10(1), 67-71.

Kalnejais, L.H., Martin, W.R., and Bothner, M.H. (2010). The release of dissolved nutrients and metals from coastal sediments due to resuspension. Mar. Chem., 121(1-4), 224-235. http://dx.doi.org/10. 1016/j.marchem.2010.05.002

Loperfido, J.V., Just, C.L., Papanicolaou, A.N., and Schnoor, J.L. (2010). In situ sensing to understand diel turbidity cycles, suspended solids, and nutrient transport in Clear Creek, Iowa. Water Resour. Res., 46(6), W06525. http://dx.doi.org/10.1029/2009WR00 8293

Mattiuzzo, E., Favero, L., Zennaro, F., and Franco, D. (2007). Heavy metal behaviour in an experimental free water surface wetland in the Venice Lagoon Watershed. Water Air Soil Pollut., 183(1-4), 143-151. http://dx.doi.org/10.1007/s11270-007-9363-7
Olsen, C.R., Cutshall, N.H., and Larsen, I.L. (1982). Pollutant-particle associations and dynamics in coastal marine environments: A review. Mar. Chem., 11(6), 501-533. http://dx.doi.org/10.1016/030 4-4203(82)90001-9

Rügner, H., Schwientek, M., Beckingham, B., Kuch, B., and Grathwohl, P. (2013). Turbidity as a proxy for total suspended solids (TSS) and particle facilitated pollutant transport in catchments. Environ. Earth Sci., 69(2), 373-380. http://dx.doi.org/10.1007/s126 65-013-2307-1

Roberts, D.A. (2012). Causes and ecological effects of resuspended contaminated sediments (RCS) in marine environments. Environ. Int., 40, 230-43. http://dx.doi.org/10.1016/j.envint.2011.11.013

Shine, J.P., Ika, R., and Ford, T.E. (1998). Relationship between oxygen consumption and sediment-water fluxes of heavy metals in coastal marine sediments. Environ. Toxicol. Chem., 17(11), 23252337. http://dx.doi.org/10.1002/etc.5620171125

Singh, S.P., Tack, F.M.G., Gabriels, D., and Verloo, M.G. (2000). Heavy metal transport from dredged sediment derived surface soils in a laboratory rainfall simulation experiment. Water Air Soil Pollut., 118(1-2), 73-86. http://dx.doi.org/10.1023/A:1005140726372

Stephens, S.R., Alloway, B.J., Parker, A., Carter, J.E., and Hodson, M.E. (2001). Changes in the leachability of metals from dredged canal sediments during drying and oxidation. Environ. Pollut., 114 (3), 407-413. http://dx.doi.org/10.1016/S0269-7491(00)00231-1

Stone, M., and Droppo, I.G. (1996). Distribution of lead, copper and zinc in size-fractionated river bed sediment in two agricultural catchments of southern Ontario, Canada. Environ. Pollut., 93(3), 353-362. http://dx.doi.org/10.1016/S0269-7491(96)00038-3

Uhrich, M.A., and Bragg, H.M. (2000). Monitoring Instream Turbidity to Estimate Continuous Suspended-Sediment Loads and Yields and Clay-Water Volumes in the Upper North Santiam River Basin, Oregon, 1998-2000, United States Geological Survey Water-Resources Investigations Report 03-4098, USA.

Uluturhan, E., Kontas, A., and Can, E. (2011). Sediment concentrations of heavy metals in the Homa Lagoon (Eastern Aegean Sea): Assessment of contamination and ecological risks. Mar. Pollut. Bull., 62(9), 1989-1997. http://dx.doi.org/10.1016/j.marpolbul.20 11.06.019

van Griethuysen, C., Gillissen, F., and Koelmans, A.A. (2002). Measuring acid volatile sulphide in floodplain lake sediments: Effect of reaction time, sample size and aeration. Chemosphere, 47(4), 395-400. http://dx.doi.org/10.1016/S0045-6535(01)00314-9

Wang, J., Liu, R.H., Yu, P., Tang, A.K., Xu, L.Q., and Wang, J.Y. (2012). Study on the pollution characteristics of heavy metals in seawater of Jinzhou Bay. Procedia Environ. Sci., 13, 1507-1516. http://dx.doi.org/10.1016/j.proenv.2012.01.143

Zhang, Y., Li, D., Zhang, Z., and Liao, K. (2010). A comparison study of two methods for mensuration of soil cation exchange capacity (in Chinese). Guizhou For. Sci. Tech., 38(2), 5.

Zheng, S., Wang, P., Wang, C., Hou, J., and Qian, J. (2012). Distribution of metals in water and suspended particulate matter during the resuspension processes in Taihu Lake sediment, China. Quat. Int., 286, 94-102. http://dx.doi.org/10.1016/j.quaint.2012.09.003

Zou, H., Sheng, G., Sun, C., and Xu, O. (1996). Distribution of organic contaminants in Lake Taihu. Water Res., 30(9), 2003-2008. http://dx.doi.org/10.1016/0043-1354(96)00025-5 